\title{
Myth Dispelled
}

\section{Adam Possner}

The flu vaccine cannot

give you the flu, I tell him.

It's dead virus, there's

nothing alive about it.

It can't make you sick.

That's a myth.

But if we bury it in

the grassy knoll

of your shoulder,

an inch under the stratum

corneum, as sanctioned by

your signature

in a white-coated ceremony

presided over by

my medical assistant

and then mark the grave

with a temporary

non-stick headstone,

the trivalent spirit

of that vaccine

has a 70 to 90 percent

chance of warding off

the Evil One,

and that's the God's

honest truth.

Dr Possner is an assistant professor of general internal medicine at George Washington University in Washington, DC. His areas of interest include preventive medicine and medical student and resident education.

Author affiliation: George Washington University, Washington, DC, USA
Address for correspondence: Adam Possner, Medical Faculty Associates, George Washington University, 2150 Pennsylvania Ave NW, Suite 5-416 North, Washington, DC 20037, USA; email: apossner@mfa.gwu.edu

From JAMA, December 5, 2012. (C) American Medical Association, 2012. Reprinted with permission.

DOI: http://dx.doi.org/10.3201/eid1904.ET1904 